Al-Manhaj: Jurnal Hukum dan Pranata Sosial Islam

Vol. : : 2 (2), 2020, 238-254

P-ISSN : 2686-1607

E-ISSN : 2686-4819

\title{
ANALISIS YURIDIS PERBANDINGAN RISIKO MEDIS DENGAN KELALAIAN MEDIS
}

\author{
Abdul Kholib \\ Universitas Pembangunan Nasional Veteran Jakarta \\ email: kolib78@Yahoo.com
}

\begin{abstract}
Health is recognized internationally as one of the human rights that needs to be upheld, as well as in the laws of the State of Indonesia. Health services are provided to all Indonesian citizens as a mandate from the 1945 Constitution of the Republic of Indonesia. The doctor as one of the parties providing health services to the patient has responsibilities and obligations that he must fulfill to the patient, where the patient's expectation of the health services provided by the doctor is that the patient gets healing as there is a therapeutic agreement agreed between the patient and the doctor. But sometimes there are some conditions that result in the results of health services provided by doctors to patients not in accordance or far from what has been expected by both parties, where it can be called a medical risk, and those that occur due to medical negligence, but both - both have 2 (two) different consequences, so in this study will discuss the comparison between medical negligence with medical risks. This research has 2 (two) formulations of the problem, namely: (1) How is the determination of the doctor's medical action as a medical negligence or medical risk ?; and (2) How is the comparative analysis between medical negligence and medical risk ?. The research method used is juridical-normative legal research, with the support of secondary data consisting of: (1) primary legal material: the 1945 Constitution of the Republic of Indonesia, the Criminal Code (KUHP), Universal Declaration of Human Rights,
\end{abstract}


Law No. 36 of 2009 concerning Health, Law No. 29 of 2004 concerning Medical Practice, and Government Regulation No. 290 / MENKES / PER / III / 2008 concerning Approval of Medical Measures; (2) secondary legal materials: health law textbooks, and health law journals; and (3) tertiary legal material: Language dictionaries and terms.

Keywords: Health Services, Medical Risk, Medical Negligence

Abstrak: Kesehatan diakui di dunia internasional sebagai salah satu dari Hak Asasi Manusia yang perlu dijunjung tinggi, begitupula dalam hukum Negara Indonesia. Pelayanan kesehatan diberikan kepada seluruh warga negara Indonesia sebagai amanat dari Undang-Undang Dasar Negara Republik Indonesia Tahun 1945. Dokter sebagai salah satu Pihak yang memberikan pelayanan kesehatan kepada Pasien memiliki tanggungjawab serta kewajiban yang harus ia penuhi terhadap Pasien, dimana harapan Pasien atas pelayanan kesehatan yang diberikan oleh Dokter adalah Pasien memperoleh kesembuhan sebagaimana adanya perjanjian terapeutik yang disepakati diantara Pasien dengan Dokter. Namun adakalanya terdapat adanya beberapa kondisi yang mengakibatkan hasil pelayanan kesehatan yang diberikan oleh Dokter kepada Pasien tidak sesuai atau jauh dari apa yang telah diharapkan oleh kedua belah Pihak, dimana hal tersebut dapat disebut sebagai risiko medis, dan adapula yang terjadi akibat kelalaian medis, namun kedua-duanya memiliki 2 (dua) konsekuensi yang berbeda, sehingga dalam penelitian ini akan membahas mengenai perbandingan antara kelalaian medis dengan resiko medis. Penelitian ini memiliki 2 (dua) rumusan masalah, yaitu: (1) Bagaimana penentuan tindakan medis dokter sebagai suatu kelalaian medis atau resiko medis?; dan (2) Bagaimana analisis perbandingan antara kelalaian medis dengan resiko medis?. Metode penelitian yang digunakan adalah penelitian hukum yuridis-normatif, dengan dukungan data sekunder yang terdiri dari: (1) bahan hukum primer: Undang-Undang Dasar Negara Republik Indonesia Tahun 1945, Kitab Undang-Undang Hukum Pidana (KUHP), Universal Declaration of Human Rights, Undang-Undang No. 36 Tahun 2009 tentang Kesehatan, UndangUndang No. 29 Tahun 2004 Tentang Praktik Kedokteran, dan Peraturan Pemerintah No. 290/MENKES/PER/III/2008 tentang 
Persetujuan Tindakan Kedokteran; (2) bahan hukum sekunder: buku teks hukum kesehatan, dan jurnal hukum kesehatan; dan (3) bahan hukum tersier: kamus Bahasa dan istilah.

Kata Kunci: Pelayanan Kesehatan, Risiko Medis, Kelalaian Medis

\section{PENDAHULUAN}

Kesehatan diakui di dunia internasional sebagai salah satu dari Hak Asasi Manusia yang perlu dijunjung tinggi. Dalam kepustakaan kesehatan, terdapat berbagai istilah yang digunakan untuk menyebut hak asasi manusia di bidang kesehatan, seperti "hak asasi atas kesehatan" (Human Right to Health), atau "hak atas kesehatan" (Right to Health), atau "hak memperoleh derajat kesehatan yang optimal" (The Right to Attainable Standard To Health). ${ }^{1}$ Perserikatan Bangsa-Bangsa (PBB) pada tahun 1948 telah menetapkan Universal Declaration of Human Rights, yang di dalamnya mengatur hak atas kesehatan dimana pada Pasal 25 ayat 1 dan 2 Universal Declaration of Human Rights yang berbunyi: "Setiap orang berhak untuk hidup dengan standar hidup yang layak bagi dirinya maupun bagi keluarganya, mencakup juga pemenuhan kebutuhan makanan dan minuman, pakaian, perumahan, pelayanan kesehatan serta pelayanan sosial lainnya. Selain itu, adanya jaminan bila dalam keadaan tidak bekerja, sakit, cacat, bercerai, lanjut usia dan Iain-Iain diluar batas kemampuannya. Baik ibu maupun anak, berhak untuk

${ }^{1}$ Eleanor D. Kinney, "The International Human Right to Health", Indiana Law Review, Vol 34, 1559. 
mendapatkan perlindungan tertentu. Semua anak baik yang lahir di dalam maupun di luar perkawinan, harus mendapatkan perlindungan sosial yang sama.

Begitupula dalam hukum Negara Indonesia dimana kesehatan sebagai hak asasi manusia dijamin dalam UndangUndang Dasar Negara Republik Indonesia Tahun 1945, yang kemudian diejawantahkan ke dalam suatu undang-undang khusus yaitu Undang-Undang No. 36 Tahun 2009 tentang Kesehatan dimana pada Pasal 4 undang-undang tersebut berbunyi: "Setiap orang berhak atas kesehatan." Pelayanan kesehatan diberikan kepada seluruh warga negara Indonesia sebagai amanat dari Pasal 28H ayat (1) Undang-Undang Dasar Negara Republik Indonesia Tahun 1945 yang berbunyi: "setiap orang berhak hidup sejahtera lahir dan batin, bertempat tinggal dan mendapatkan lingkungan hidup yang baik dan sehat serta berhak memperoleh pelayanan kesehatan".

Dokter sebagai salah satu Pihak yang memberikan pelayanan kesehatan kepada Pasien memiliki tanggungjawab serta kewajiban yang harus ia penuhi. Kewajiban Dokter dapat dijabarkan berdasarkan Pasal 51 Undang-Undang No. 29 Tahun 2004 Tentang Praktik Kedokteran, yang berbunyi: "Dokter atau dokter gigi dalam melaksanakan praktik kedokteran mempunyai kewajiban : (1) memberikan pelayanan medis sesuai dengan standar profesi dan standar prosedur operasional serta kebutuhan medis pasien; (2) merujuk pasien ke dokter atau dokter gigi lain yang mempunyai keahlian atau kemampuan yang lebih baik, apabila tidak mampu melakukan suatu pemeriksaan atau 
pengobatan; (3) merahasiakan segala sesuatu yang diketahuinya tentang pasien, bahkan juga setelah pasien itu meninggal dunia; (4) melakukan pertolongan darurat atas dasar perikemanusiaan, kecuali bila ia yakin ada orang lain yang bertugas dan mampu melakukannya; dan (5) menambah ilmu pengetahuan dan mengikuti perkembangan ilmu kedokteran atau kedokteran gigi.

Dokter menyelenggarakan upaya kesehatan dimana berdasarkan Pasal 1 butir 11 Undang-Undang No. 36 Tahun 2009 tentang Kesehatan, yang menyebutkan: “Upaya kesehatan adalah setiap kegiatan dan/atau serangkaian kegiatan yang dilakukan secara terpadu, terintregasi dan berkesinambungan untuk memelihara dan meningkatkan derajat kesehatan masyarakat dalam bentuk pencegahan penyakit, peningkatan kesehatan, pengobatan penyakit, dan pemulihan kesehatan oleh pemerintah dan/atau masyarakat." Pengendalian kualitas pelayanan kesehatan dilakukan sejak dari pendidikan, memberi kewenangan dokter dan dokter gigi untuk berpraktik dengan prasyarat terregistrasi dan melakukan pembinaan lebih lanjut setelah berpraktik. ${ }^{2}$ Ekspektasi pasien merupakan harapan pasien atas pelayanan kesehatan yang diterimanya. ${ }^{3}$ Harapan Pasien atas pelayanan kesehatan yang diberikan oleh Dokter adalah Pasien memperoleh kesembuhan sebagaimana adanya perjanjian terapeutik yang disepakati diantara Pasien dengan Dokter. Perjanjian Terapeutik sebagai

2 Konsil Kedokteran Indonesia, Penyelenggaraan Praktik Kedokteran yang Baik di Indonesia, (Jakarta: 2006), 3.

3 Lateef F., Patient Expectations and The Paradigm Shift of Care in Emergency Medicine, (J Emerg Trauma Shock, 2011) 163. 
kontrak yang dibuat antara pasien dengan Dokter dimana Dokter berusaha melakukan upaya maksimal untuk melakukan penyembuhan terhadap pasien sesuai dengan kesepakatan yang dibuat antara keduanya dan pasien berkewajiban membayar biaya penyembuhannya. ${ }^{4}$ Namun adakalanya terdapat adanya beberapa kondisi yang mengakibatkan hasil pelayanan kesehatan yang diberikan oleh Dokter kepada Pasien tidak sesuai atau jauh dari apa yang telah diharapkan oleh kedua belah Pihak, dimana hal tersebut dapat disebut sebagai risiko medis, dan adapula yang terjadi akibat kelalaian medis.

Dewasa ini penentuan akibat dari suatu tindakan medis sebagai risiko medis atau kelalaian medis seringkali tidak jelas, padahal terdapat adanya unsur-unsur perbuatan yang berbeda baik antara risiko medis dengan kelalaian medis sehingga apabila terdapat adanya kekaburan dalam penentuan tindakan medis dapat mengakibatkan kerugian terhadap kedua belah pihak, khususnya Dokter dimana apabila suatu akibat dari tindakan medis yang dianggap kelalaian medis namun seyogyanya akibat dari tindakan medis tersebut dapat dikategorikan sebagai risiko medis, maka Dokter yang melakukan tindakan medis harus mempertanggungjawabkannya, meskipun akibat tersebut diluar dari kehendaknya karena termasuk risiko medis, sehingga perlu adanya pembahasan mengenai perbandingan antara kelalaian medis dengan resiko medis.

4 H.S, Salim, Hukum Kontrak Teori dan Teknik Penyusunan Kontrak (Jakarta: Sinar Grafika, 2004), 46. 
Jaminan pelayanan kesehatan sebagai hak asasi khususnya bagi Warga Negara Indonesia telah dijamin dalam pasal 28H ayat (1) Undang-Undang Dasar Negara Republik Indonesia Tahun 1945: "setiap orang berhak hidup sejahtera lahir dan batin, bertempat tinggal dan mendapatkan lingkungan hidup yang baik dan sehat serta berhak memperoleh pelayanan kesehatan". Definisi pelayanan kesehatan menurut Depkes RI (2009) adalah setiap upaya yang diselenggarakan sendiri atau secara bersamasama dalam suatu organisasi untuk memelihara dan meningkatkan kesehatan, mencegah dan menyembuhkan penyakit serta memulihkan kesehatan perorangan, keluarga, kelompok dan atupun masyarakat. Sesuai dengan batasan seperti di atas, mudah dipahami bahwa bentuk dan jenis pelayanan kesehatan yang ditemukan banyak macamnya. Karena kesemuanya ini ditentukan oleh pengorganisasian pelayanan, apakah dilaksanakan secara sendiri atau secara bersama-sama dalam suatu organisasi, dan ruang lingkup kegiatan, apakah hanya mencakup kegiatan pemeliharaan kesehatan, pencegahan penyakit, penyembuhan penyakit, pemulihan kesehatan atau kombinasi dari padanya. ${ }^{5}$

Metode penelitian yang digunakan dalam penelitian ini adalah penelitian hukum yuridis-normatif, dengan dukungan data sekunder yang terdiri dari: (1) bahan hukum primer: UndangUndang Dasar Negara Republik Indonesia Tahun 1945, Kitab Undang-Undang Hukum Pidana (KUHP), Universal Declaration of

${ }^{5}$ Dahlan Sofyan, Hukum Kesehatan, Rambu-rambu bagi Profesi Dokter (Semarang: UNDIP, 1999), 55. 
Human Rights, Undang-Undang No. 36 Tahun 2009 tentang Kesehatan, Undang-Undang No. 29 Tahun 2004 Tentang Praktik Kedokteran, dan Peraturan Pemerintah No. 290/MENKES/PER/III/2008 tentang Persetujuan Tindakan Kedokteran; (2) bahan hukum sekunder: buku teks hukum kesehatan, dan jurnal hukum kesehatan; dan (3) bahan hukum tersier: kamus Bahasa dan istilah.

\section{PENENTUAN TINDAKAN MEDIS DOKTER SEBAGAI SUATU KELALAIAN MEDIS ATAU RESIKO MEDIS}

Dokter memiliki kewajiban salah satunya adalah menyelenggarakan pelayanan kesehatan. Pada dasarnya praktik dokter merupakan pemberian bantuan secara individual oleh dokter kepada pasien berupa pelayanan medis. Apabila seseorang datang kepada dokter untuk memanfaatkan pelayanan medis yang tersedia maka terjadi hubungan hukum antara dokter dan pasien yang disebut tranksaksi terapeutik. Hubungan hukum yang tidak menjanjikan sesuatu kesembuhan atau kematian semacam ini disebut inspanningsverbintenis, yang berbeda dengan hubungan hukum yang biasa berlaku dalam perjanjian pada umumnya yang menjanjikan suatu hasil yang pasti (risikoverbentenis/ resultaatsverbentenis). ${ }^{6}$ Oleh karena itu hasil yang didapatkan dari pelayanan kesehatan merupakan hasil yang tidak pasti namun dapat diperkirakan risiko medis yang mungkin dapat terjadi sehingga hal tersebut harus diinformasikan kepada Pasien atau

6 Widodo Tresno Novianto, "Penafsiran Hukum dalam Menentukan Unsur-unsur Kelalaian Malpraktek Medik (Medical Malpractice)", Jurnal Yustisia Vol. 4 No. 2 Mei -Agustus 2015, 489. 
Keluarga Pasien terlebih dahulu, sehingga keputusan ada di tangan Pasien atau Keluarga Pasien untuk setuju atau tidak menyetujui tindakan medis yang akan dilakukan Dokter dimana untuk menginformasikan risiko medis merupakan Kewajiban Dokter sebagaimana yang diatur dalam Undang-Undang No. 29 Tahun 2004 Tentang Praktik Kedokteran yang pada intinya sebelum dilakukan tindakan kedokteran terhadap pasien harus mendapat persetujuan terlebih dahulu setelah pasien mendapat penjelasan secara lengkap yang sekurang-kurangnya mencakup diagnosis dan tata cara tindakan medis, tujuan tindakan medis yang dilakukan, alternatif tindakan lain dan risikonya, risiko dan komplikasi yang mungkin terjadi, dan prognosis terhadap tindakan yang dilakukan. ${ }^{7}$

Risiko medis yang terjadi diluar kehendak Dokter maupun Pasien mengakibatkan gugurnya tanggung jawab oleh Dokter, sehingga dalam hal penentuan akibat dari tindakan medis sebagai suatu risiko medis sehingga Dokter tidak dapat dipersalahkan atas akibat medis tersebut dapat dijabarkan sebagai berikut.

Apabila Dokter telah melakukan tindakan medis sesuai dengan standar profesi, standar medis dan standar operasional prosedur. Adapun hal tersebut telah menjadi kewajiban Dokter berdasarkan Undang-Undang No. 29 Tahun 2004 Tentang Praktik Kedokteran, dengan penjabaran sebagai berikut:

7 Undang-undang No. 29 Tahun 2004 Tentang Praktik Kedokteran, Pasal 45 ayat (1), (2) dan (3). 
1. Pasal 44 ayat (1) Undang-Undang No. 29 Tahun 2004 Tentang Praktik Kedokteran: "Dokter atau dokter gigi dalam menyelenggarakan praktik kedokteran wajib mengikuti standar pelayanan kedokteran atau kedokteran gigi." Pasal Penjelasan: "Yang dimaksud dengan "standar pelayanan" adalah pedoman yang harus diikuti oleh dokter atau dokter gigi dalam menyelenggarakan praktik kedokteran."

2. Pasal 44 ayat (2) Undang-Undang No. 29 Tahun 2004 Tentang Praktik Kedokteran: "Standar pelayanan sebagaimana dimaksud pada ayat (1) dibedakan menurut jenis dan strata sarana pelayanan kesehatan." Pasal Penjelasan: "Yang dimaksud dengan "strata sarana pelayanan" adalah tingkatan pelayanan yang standar tenaga dan peralatannya sesuai dengan kemampuan yang diberikan."

Apabila hal tersebut telah dipenuhi oleh Dokter, maka Dokter mempunyai hak untuk memperoleh perlindungan hukum sepanjang melaksanakan tugas sesuai dengan standar profesi dan standar prosedur operasional. ${ }^{8}$

Persetujuan medis yang telah diberikan oleh Pasien dan/atau Keluarga Pasien, yang dapat disebut dengan informed consent. Informed consent secara harfiah terdiri dari dua kata yaitu informed dan consent. Informed berarti telah mendapat penjelasan atau informasi; sedangkan consent berarti memberi persetujuan atau mengizinkan, dengan demikian informed consent berarti

8 Undang-undang No. 29 Tahun 2004 Tentang Praktik Kedokteran, Pasal 50 huruf a. 
suatu persetujuan yang diberikan setelah mendapat informasi. ${ }^{9}$ Sebelum melakukan tindakan medis, dokter berkewajiban memberikan penjelasan terhadap Pasien dan/atau Keluarga Pasien tentang diagnosis dan juga tata cara tindakan medis, tujuan untuk tindakan medis yang dilakukan, serta alternatif tindakan lain berikut risikonya yang akan terjadi, sehingga dengan persetujuan yang diberikan baik itu oleh Pasien maupun Keluarga Pasien dianggap telah mengetahui adanya risiko yang akan terjadi, sehingga apabila terjadi risiko medis sebagaimana yang telah diketahui sebelumnya, maka terhadap risiko itu tidak dapat dipersalahkan kepada Dokter.

Mengenai persetujuan tindakan medis tersebut telah diatur dalam Pasal 39 dan 45 Undang-Undang No. 29 Tahun 2004 Tentang Praktik Kedokteran, dan Peraturan Pemerintah No. 290/MENKES/PER/III/2008 tentang Persetujuan Tindakan Kedokteran. Berbeda halnya dengan kelalaian medis dimana kelalaian medis atau dapat disebut sebagai malpraktik medis merupakan hal yang bertolak belakang dengan risiko medis. Pengertian malpraktik medis sebagaimana yang di kemukakan oleh Adami Chazawi, bahwa malpraktik kedokteran adalah dokter atau orang yang ada di bawah perintahnya dengan sengaja atau kelalaian melakukan perbuatan (aktif atau pasif) dalam praktik kedokteran pada pasiennya dalam segala tingkatan yang melanggar standar profesi, standar prosedur, atau prinsip-prinsip

${ }_{9}$ Husein Kerbala, Segi-segi Etis dan Yuridis Informed Consent (Jakarta: Pustaka Sinar Harapan, 2000), 57. 
profesional kedokteran, atau dengan melanggar hukum atau tanpa wewenang disebabkan: tanpa informed consent atau di luar informed consent, tanpa Surat Izin Praktik (SIP) atau tanpa Surat Tanda Registrasi (STR), tidak sesuai dengan kebutuhan medis pasien; dengan menimbulkan akibat (causal verband) kerugian bagi tubuh, kesehatan fisik maupun mental atau nyawa pasien, dan oleh sebab itu membentuk pertanggungjawaban hukum bagi dokter. $^{10}$

\section{ANALISIS PERBANDINGAN ANTARA KELALAIAN MEDIS DENGAN RESIKO MEDIS}

Dalam suatu tindak medik tertentu, selalu ada risiko yang melekat pada tindak medik tersebut (inherent risk of treatment). Apabila dokter melakukan tindak medik tersebut dengan hati-hati, seizin pasien dan berdasarkan SPM (Standar Pelayanan Medik), tetapi ternyata risiko itu tetap terjadi, maka dokter itu tidak dapat dipersalahkan. ${ }^{11}$ Hal tersebut dapat disebut sebagai risiko medis sebagaimana yang telah dibahas pada bagian sebelumnya. Risiko medis adalah suatu peristiwa medis atau kondisi tidak pasti yang tidak diharapkan oleh si pasien maupun dokter.

Guwandi menyusun sistematika untuk beberapa dasar peniadaan hukuman atau kesalahan khusus bidang medis, yaitu: ${ }^{12}$

10 Adami Chazawi, 2007, Malpraktik Kedokteran: Tinjauan Norma dan Doktrin Hukum (Malang: Bayumedia, 2007), 85.

11 Mohamad Rizky Pontoh, "Penegakan Hukum Pidana Terhadap Resiko Medik Dan Malpraktek Dalam Pelaksanaan Tugas Dokter”, Jurnal Lex Crimen Vol. II/No. 7/November/2013, 78.

12 Guwandi, Hukum Medik (Medical Law) (Jakarta: Fakultas Kedokteran Universitas Indonesia, 2004), 46. 
1. Risiko pengobatan (risk of treatment): risiko yang inheren atau melekat, reaksi alergi, komplikasi dalam tubuh pasien.

2. Kecelakaan medik (medical accident).

3. Kekeliruan penilaian klinis (Non-negligent error of judgement).

4. Volenti non fit iniura.

5. Contributory negligence.

Menurut Guwandi istilah malpraktik adalah berbeda dengan istilah kelalaian medis. Menurut beliau Kelalaian merupakan bagian dari malpraktik, tetapi di dalam malpraktik tidak selalu harus terdapat unsur kelalaian. ${ }^{13}$ Jika dilihat dari definisinya, malpraktik tersebut berasal dari kata malpractice, yang mana mempunyai pengertian lebih luas dari makna kelalaian yang berasal dari kata negligence.

Apabila dianalisa dari sisi pemidanaan, dimana tindak pidana biasa yang menjadi titik perhatian utama adalah akibat dari tindakan tersebut, sedangkan dalam tindak pidana medis justru kausa atau sebab serta proses dan bukan akibat tadi, hal tersebut dikarenakan dokter dalam menjalankan profesinya mendasarkan pada usaha sebaik-baiknya (inspanningverbintenis) bukan berdasarkan hasil (resultaatverbintenis). ${ }^{14}$ Akibat yang terjadi atas tindakan medis dokter sebagai faktor utama yang dapat menentukan apakah terhadap Pasien dilakukan kelalaian medis ataukah risiko medis.

13 Guwandi, 20.

14 Crisdiono M Achadiat, 2007, Dinamika Etika dan Hukum Kedokteran dalam Tantangan Zaman (Jakarta: Penerbit Buku Kedokteran EGC, 2007), 110. 
Di dalam Kitab Undang-Undang Hukum Pidana (KUHP), perbuatan yang menyebabkan orang lain luka berat atau mati yang dilakukan secara tidak sengaja dirumuskan didalam Pasal 359 dan 360 KUHP. Adapun unsur-unsur dari pasal 359 dan 360 adalah sebagai berikut:

1. Adanya unsur kelalaian (culpa).

2. Adanya wujud perbuatan tertentu.

3. Adanya akibat luka berat atau matinya orang lain.

4. Adanya hubungan kausal antara wujud perbuatan dengan akibat kematian orang lain itu.

Berdasarkan hal tersebut, apabila dibandingkan antara risiko medis dengan malpraktik medis, baik risiko medis dengan malpraktik medis terkandung unsur wujud perbuatan tertentu, adanya akibat luka berat atau matinya orang lain, dan adanya hubungan kausal antara wujud perbuatan dengan akibat kematian orang lain itu, dimana perbuatan tersebut sama-sama berakibat luka berat maupun matinya orang lain. Namun terdapat adanya 1 (satu) unsur yang berbeda dari risiko medis dengan malpraktik medis, yaitu pada risiko medis tidak ditemukan adanya unsur kelalaian, sedangkan pada malpraktik medis jelas ditemukan adanya unsur kelalaian.

Selain itu, khusus didalam pelayanan kesehatan, kelalaian juga dikaitkan dengan pelayanan yang tidak memenuhi (dibawah) standar profesi (standar pelayanan medis) yang dalam prakteknya juga perlu digunakan untuk membedakan antara risiko medis dan malpraktik medis. Apabila terhadap pasien telah dilakukan prosedur sesuai standar pelayanan medis, namun terhadap Pasien 
terjadi luka berat atau mati, hal tersebut merupakan risiko medis. sedangkan bagi pasien yang mengalami luka berat maupun kematian sebagai akibat dokter melakukan pelayanan dibawah standar medis, maka hal ini disebut sebagai malpraktik medis. ${ }^{15}$

\section{KESIMPULAN}

Kesimpulan yang dapat diberikan dari bagian pembahasan penelitian ini mengenai penentuan tindakan medis serta analisis perbandingan antara kelalaian medis dengan resiko medis bahwa hubungan hukum antara dokter dan pasien yang disebut tranksaksi terapeutik tidak dapat menjanjikan hasil yang pasti dimana Dokter berusaha melakukan upaya maksimal untuk melakukan penyembuhan terhadap pasien, sehingga timbul kemungkinan terjadinya risiko medis diluar kehendak Dokter maupun Pasien, sehingga seharusnya telah diinformasikan terlebih dahulu terhadap Pasien dan/atau Keluarga Pasien, sedangkan kelalaian medis tidak demikian, kemudian yang menjadi faktor pembeda antara risiko medis dengan kelalaian medis atau malpraktik medis adalah ditemukan adanya unsur kelalaian pada malpraktik medis, sedangkan pada risiko medis tidak ada unsur kelalaian, selain itu risiko medis terjadi setelah pelayanan medis dilakukan dengan telah memenuhi standar pelayanan medis, sedangkan malpraktik medis terjadi apabila

15 Anny Isfandyarie, Malpraktek dan Resiko Medik (Jakarta: Prestasi Pustaka, 2005), 125. 
pelayanan medis tidak dilakukan sesuai dengan standar pelayanan medis.

\section{DAFTAR PUSTAKA}

Achadiat, Crisdiono M. Dinamika Etika dan Hukum Kedokteran dalam Tantangan Zaman. Jakarta: Penerbit Buku Kedokteran EGC, 2007.

Chazawi, Adami. Malpraktik Kedokteran: Tinjauan Norma dan Doktrin Hukum. Malang: Bayumedia, 2007.

F., Lateef. Patient expectations and the paradigm shift of care in emergency medicine, J Emerg Trauma Shock, 2011.

Guwandi, Hukum Medik (Medical Law). Jakarta: Fakultas Kedokteran Universitas Indonesia, 2004.

Indonesia, Undang-undang Dasar Negara Republik Indonesia Tahun 1945.

, Peraturan Pemerintah No. 290/MENKES/PER/III/2008 tentang Persetujuan Tindakan Kedokteran.

Undang-undang No. 29 Tahun 2004 Tentang Praktik Kedokteran.

Undang-undang No. 36 Tahun 2009 tentang Kesehatan.

Isfandyarie, Anny. Malpraktek dan Resiko Medik. Jakarta: Prestasi Pustaka, 2005.

Kerbala, Husein. Segi-segi Etis dan Yuridis Informed Consent. Jakarta: Pustaka Sinar Harapan, 2000.

Kinney, Eleanor D. "The International Human Right to Health", Indiana Law Review, Vol 34.

Kitab Undang-Undang Hukum Pidana (KUHP).

Konsil Kedokteran Indonesia, Penyelenggaraan Praktik Kedokteran Yang Baik di Indonesia. Jakarta: 2006.

Novianto, Widodo Tresno. "Penafsiran Hukum Dalam Menentukan Unsur-Unsur Kelalaian Malpraktek Medik (Medical Malpractice)", Jurnal Yustisia Vol. 4 No. 2 Mei - Agustus 2015.

Pontoh, Mohamad Rizky. "Penegakan Hukum Pidana Terhadap Resiko Medik Dan Malpraktek Dalam Pelaksanaan Tugas Dokter", Jurnal Lex Crimen Vol. II/No. 7/November/2013.

Salim, S. Hukum Kontrak Teori dan Teknik Penyusunan Kontrak. Jakarta: Sinar Grafika, 2004. 
Sofyan, Dahlan. Hukum Kesehatan, Rambu-rambu bagi Profesi Dokter. Semarang: UNDIP, 1999.

Universal Declaration of Human Rights. 